\title{
Mengulas Dan Memahami Kinerja Guru
}

\section{Nehemia Nome}

Sekolah Tinggi Teologi Pelita Dunia, Tangerang

nehemia@gmail.com

\begin{abstract}
This study discusses how to understand teacher performance in a simple yet scientific review. Using a qualitative approach, the researcher found that the teacher's performance in this study was a success achieved by the teacher in teaching activities or the teaching and learning process. The teacher's performance can be seen from the skills in making teaching plans. Teaching skills and the ability to build interpersonal relationships.
\end{abstract}

Keywords: Teacher Performance, Christian Education, Teacher Duties.

Abstrak: Penelitian ini membahas tentang bagaimana memahami kinerja guru dalam sebuah ulasan sederhana namuan ilmiah. Menggunakan pendekatan kualitatif, peneliti menemukan bahwa kinerja guru dalam penelitian ini adalah suatu keberhasilan yang dicapai guru dalam aktivitas mengajar atau proses belajar mengajar. Kinerja guru ini terlihat dari keterampilan membuat rencana pengajaran. Keterampilan mengajar dan kemampuan membina hubungan antar pribadi.

Kata Kunci: Kinerja Guru, Pendidikan Kristen, Tugas Guru

\section{Pendahuluan}

Bagi setiap organisasi atau perusahaan, kinerja merupakan faktor yang paling penting untuk diperhatikan. Baik tidaknya kerja organisasi/perusahaan sangat tergantung pada kinerja orang-orang yang terlibat di dalamnya.

Kinerja guru pada hakikatnya adalah perilaku guru yang diperlihatkan dalam pelaksanaan tugas guna pencapaian tujuan pendidikan yang telah ditentukan. Pelaksanaan tugas dan pekerjaan bagi guru tidak terlepas dari cara guru itu bekerja.

Dalam pelaksanaan tugas, guru dituntut untuk merencanakan program pengajaran, menyusun program pengajaran, secara rinci yang akan dilaksanakan pada kegiatan belajar mengajar. Di samping itu, guru melaksanakan kegiatan pengajaran dan mengadakan evaluasi.

Apabila guru melaksanakan tugasnya dengan senang hati dan terprogram maka kegiatan mengajar akan berlangsung baik. Hal tersebut akan mendorong siswa mengikuti pelajaran dengan tekun. Dengan demikian diharapkan yang dicapai dari kegiatan belajar mengajar, akan maksimal dan dapat meningkatkan mutu pendidikan.

\section{Metode Penelitian}

Pada penelitian ini, penulis atau peneliti menggunakan pendekatan atau metode kualitatif untuk memperoleh data yang valid guna membangun sebuah teori yang berkaitan dengan tema atau pokok penelitian. Metode kualitatif yang dimaksud adalah 
mengkaji dan mengelaborasi setiap sumber, informasi dan data-data yang diperoleh dari pustaka.

\section{Hasil dan Pembahasan}

Menurut the Scribner yang dikutip oleh Suryadi : "performance / kinerja adalah hasil yang dapat dicapai oleh seorang atau sekelompok orang daam suatu organisasi bersangkutan secara illegal, tidak melanggar hukum dan sesuai dengan moral maupun etika."1

Sedangkan Mitrani mendefinisikan kinerja sebagai berikut:

Pernyataan sejauh mana seseorang telah memainkan bagiannya dalam melaksanakan strategi organisasi baik dalam mencapai sasaran - sasaran khusus yang berhubungan dengan peranan perseorangan dan / atau dengan memperlihatkan kompetensi - kompetensi yang dinyatakan relevan bagi organisasi, apakah dalam suatu peranan tertentu, atau secara lebih umum. ${ }^{2}$

Menurut kedua pakar tersebut kiinerja ditekankan sebagai suatu proses untuk mencapai hasil tertentu. Dengan demkian tinggi rendahnya kinerja seseorang dalam bekerja dapat dievaluasi dari tindakan dan perilaku yang diperlihatkan.

Dalam kamus besar Bahasa Indonesia yang dimaksud dengan kinerja adalah "Suatu yang dicapai, prestasi yang diperlihatkan atau kemampuan kerja"3 Sedangkan Gibson, Ivaneevich dan Donelly, mengungkapkan : "Kinerja sebagai presasi kerja yaitu hasil yang diinginkan dari prilaku.

Jadi jika dilihat dari definisi tersebut, maka kinerja berhubungan dengan prestasi kerja, dimana I.G Wuryanto mengemukakan, bahwa "Prestasi Kerja, adalah hasil kerja yang dicapai oleh karyawan dalam melaksanakan tugas yang dibebankan kepadanya, yang dipengaruhi kecakapan, keterampilan, pengalaman dan kesungguhan karyawan yang bersangkutan. ${ }^{4}$

Jadi dengan adanya kinerja yang baik dari orang-orang yang menjalankan roda organisasi. Maka segaa kegiatan di dalam organisasi itu dapat dilaksanakan sesuai dengan yang direncanakan agar tujuan dari organisasi dapat dicapai dengan efektif dan efisien.

\section{Kinerja Guru}

Guru bukanlah orang yang sekedar berdiri di depan kelas untuk menyampaikan materi tertentu, tetapi merupakan anggota masyarakat yang hendaknya ikut aktif berjiwa bebas serta kreatif dalam mengarahkan perkembangan anak didiknya untuk menjadi anggota masyarakat sebagai orang dewasa.

Posisi guru sebagai pemegang peran utama memberi arti bahwa jabatan guru

\footnotetext{
${ }^{1}$ Suryadi Prawiro Soentono, 1997. Manajemen Sumber Daya Manusia Kebijakan Kinerja Karyawan. Yogyakarta : BPFE. hlm. 2.

2 Alain Mitrani, dkk, 1990. Manajemen Sumber Daya Manusia Berdasarkan Kompetensi, Jakarta : Pustaka Utama Grafim.ti. hlm. 131.

${ }^{3}$ Tim Penyusun Kamus Pusat Pembinaan dan Pengembangan Bahasa,. 1996. Kamus Besar Bahasa Indonesia Edisi Kedua, Jakarta : Depdikbud Balai Pustaka, hlm. 503.

${ }^{4}$ IG. Wuryanto,1991. Manajemen Kepegawaian 2, Yogyakarta : Kanisius. hlm. 39.
} 
merupakan jabatan profesional yang membutuhkan keahlian khusus di bidang keguruan dan tidak dapat dilakukan oleh sembarang orang.

Menurut Supeno, "Guru adalah seorang yang karena panggilan jiwanya, sebagian besar waktu, tenaga dan pikirannya digunakan untuk mengajar ilmu pengetahuan, keterampilan dan sikap kepada orang lain di sekolah atau lembaga pendidikan formal."5

Sedangkan guru diartikan oleh J.S Badudu sebagai "Orang yang mengajari orang lain baik disekolah ataupun bukan."6

Wahjo Sumidjo mengatakan bahwa guru adalah "Sekelompok tenaga pelajar atau pendidik yang secara khusus diangkat dengan tugas utama mengajar pada jenjang pendidikan dasar dan menengah. ${ }^{7}$

Dari pendapat di atas dapat disimpulkan bahwa guru atau tenaga kependidikan bertugas menyelenggarakan kegiatan belajar mengajar, melatih, mengembangkan, mengelola, serta memberikan layanan teknis dalam bidang pendidikan.

Oleh karena itu sebagai orang yang terlibat langsung dalam proses belajar mengajar, maka guru dituntut untuk menciptakan kondisi yang efektif yang memungkinkan terjadinya interaksi belajar mengajar yang baik.

Seorang guru dituntut memiliki kinerja yang baik, karena guru adalah pelaku utama dalam kegiatan belajar mengajar. Menurut Gagne, bahwa guru dalam proses belajar mengajar mempunyai fungsi sebagai "Designer of Instruction, Manager of Instruction, Evaluation of Student Learning."8

Guru sebagai Designer of Instruction (perancang pengajaran) diharapkan untuk senantiasa mampu dan siap merancang kegiatan belajar mengajar yang berhasil guna dan berdaya guna.

Guru sebagai evaluator of student learning (penilai hasil pembelajaran) untuk senantiasa mengikuti perkembangan taraf kemajuan prestasi belajar atau kinerja akademik siswa dalam setiap kurun waktu pembelajaran. Ketiga fungsi ini merupakan kegiatan yang hendaknya dipandang sebagai siklus kegiatan yang berhubungan dengan yang lain.

Dari pengertian beberapa teori yang menjelaskan arti kinerja dan guru maka kinerja guru mempunyai arti tertentu, seperti yang dikemukakan oleh A Trabrani Rusyan dkk, Kinerja Guru adalah :

Melaksanakan proses pembelajaran baik dilakukan di dalam kelas maupun di luar kelas disamping mengerjakan kegiatan - kegiatan lainnya, seperti mengerjakan administrasi sekolah dan administrasi pembelajaran, melaksanakan bimbingan dan lowongan pada para siswa, serta

\footnotetext{
${ }^{5}$ Hadi Supeno, 1989. Undang-Undang Indonesia, Nomor 11 Tahun 1989. Tentang Sistem Pendidikan Nasional Beserta Penjelasan. Jakarta : Balai Pustaka, hl. 27

${ }^{6}$ Ibid. hlm. 527.

${ }^{7}$ Wahjo Sumidjo. 2001. Kepemimpinan Kepala Sekolah. Jakarta : Raja Grafindo Persada. hlm. 191.

${ }^{8}$ Muhibbin Syah, 1995. Psikologi Pendidikan. Dengan Pendekatan Baru, Bandung: Remaja Rosdakarya, hlm. 251.
} 
melaksanakan penilaian - panilaian. ${ }^{9}$

Selanjutnya seperti yang disimpulkan oleh Hary Widyastono berdasarkan kemampuannya dalam penelitian tentang kinerja guru sekolah dasar bahwa kinerja guru dimaksudkan sebagai "Perbuatan yang ditampilkan guru yang dapat diamati selama proses belajar mengajar berlangsung."10

Dari pendapat - pendapat di atas dikatakan bahwa kinerja guru adalah perbuatan atau perilaku guru yang diperlihatkan pada waktu proses belajar mengajar berlangsung dalam rangka mencapai tujuan yang telah ditetapkan.

Salah satu usaha guna meningkatkan kinerja guru, Hasley dalam Made Pidarta menyatakan bahwa cara menciptakan moral kerja sebagai berikut :

1. Memerlukan kesempatan mewujudkan kepribadiannya dalam pekerjaan sehingga merasa bangga dan puas.

2. Usaha - usaha yang dihargai, ditujukan perhatian bahwa pekerjaan itu penting walaupun tingkat pekerjaan itu rendah.

3. Usahakan agar petugas itu percaya bahwa setiap pekerjaanya bermanfaat sehingga ia bergairah kerja. ${ }^{11}$

Dari uraian di atas dapat disimpulkan secara singkat bahwa moral kerja ini menggambarkan dedikasi seseorang dalam melaksanakan tugas.

\section{Aspek-aspek Kinerja Guru}

Kinerja guru sangat erat kaitannya dengan budaya kerja. Sedangkan budaya kerja merupakan salah satu upaya dan perbuatan untuk meningkatkan kualitas kerja, karena dengan budaya kerja segala kegiatan pekerjaan dan tugas akan teratur dan terarah, sehingga tujuan kerja yang diharapkan dapat dicapai dengan baik.

Menurut A. Tabrani Rusyan, dkk, aspek-aspek kinerja guru ditandai dengan :

1. Semua pekerjaan dapat dilaksanakan dengan terarah, tertib dan teratur, sehingga tujuan yang diharapkan mudah untuk dicapai.

2. Kreatifitas guru dapat terpusat kesatu arah tujuan yang tepat.

3. Guru bekerja dinamis dan inovatif, sehingga semua hal yang dikerjakan akan menghasilkan sesuatu yang berguna.

4. Aktivitas kerja lebih meningkatkan kualitas kerjanya

5. Semua kegiatan kerja bisa dilaksanakan secara efektif dan efisien.

6. Semua aktivitas kerja yang sedang berlangsung dapat memberikan suasana yang menyenangkan dan harmonis.

7. Hasil kerja bisa optimal

8. Mendorong guru untuk melaksanakan pekerjaan secara bekerja sama dan menghasilkan. Suatu pencapaian tujuan yang optimal dalam waktu singkat.

\footnotetext{
${ }^{9}$ A. Tabrani Rusyan, dkk. 2001. Upaya Meningkatkan Kinerja Guru. Jakarta : Nusantara Lestari Ceria Pratama, hlm. 17.

${ }^{10}$ Harry Widyastono. 1990. Kinerja Guru Sekolah Dasar, Jakarta :Bina Aksara. hlm. 32

${ }^{11}$ Made Pidarta, 1990. Manajemen Pendidikan Indonesia. Jakarta : Bina Aksara, hml. 32.
} 
9. Suasana dan situasi kerja mengarahkan pada tujuan dan program kerja. ${ }^{12}$

Sementara itu Kegiatan Belajar Mengajar terdiri dari beberapa komponen yang saling berinteraksi satu sama lain dalam satu ikatan untuk mencapai tujuan. Menurut Moh. Uzer Usman sebagai seorang guru dalam melaksanakan tugas satu kali proses mengajar melaksanakan hal- hal sebagai berikut:

Merumuskan Tujuan Pembelajaran Khusus (TPK) yang dicapai. Langkah berikutnya ialah menentukan materi pelajaran yang sesuai dengan tujuan tersebut. Selanjutnya menentukan metode mengajar yang merupakan wahana pengembangan materi pelajarna sehingga dapat diterima dan menjadi milik siswa. Kemudian menentukan alat peraga pelajaran yang dapat digunakan untuk memperjelas dan mempermudah penerimaan materi pelajaran oleh siswa serta dapat menunjang tercapainya tujuan tersebut. Langkah yang terakhir adalah menentukan alat evaluasi yang dapat mengukur tercapai tidaknya tujuan yang hasilnya dapat dijadikan sebagai feed back bagi guru dalam meningkatkan kualitas mengjarnya maupun kuantitas belajar siswa. ${ }^{13}$

Dari pendapat-pendapat di atas dapat disimpulkan bahwa aspek-aspek kinerja guru akan terlihat dari :

1. Menyusun program pengajaran

2. Membuat program satuan pelajaran

3. Melaksanakan kegiatan belajar mengajar

4. Mengevaluasi

5. Menganalisa soal

6. Remedial

Bila guru telah melaksanakan kewajibannya seperti tersebut di atas, besar kemungkinan yang dicapai akan optimal.

Aspek - aspek kinerja guru yang telah diuraikan di atas hendaknya dimiliki oleh setiap guru agar dapat melaksanakan tugas secara maksimal. Guru yang melaksnakan aspek-aspek kinerja guru akan dapat meningkatkan kinerjanya. Kinerja guru yang berupa kegiatan belajar mengajar apabila meningkat berpengaruh terhadap hasil yang dicapai, sehingga secara keseluruhan dapat pula meningkatkan mutu pendidikan.

\section{Faktor-faktor yang Mempengaruhi Kinerja Guru}

Untuk mendukung keberhasilan kinerja guru menurut A. Tabarani Rusyan, dkk, ada berbagai faktor yang mempengaruhi, diantaranya adalah sebagai berikut :

1. Motivasi kinerja guru

2. Etos kerja guru

3. Lingkungan kinerja guru

\footnotetext{
${ }^{12}$ A. Tabrani Rusyan, dkk. Op. Cit h.m 48-49.

${ }^{13}$ Moh Uzer Usman. 1995. Menjadi Guru Profesional . Bandung : Remaja Rosdakarya. . 5
} 
4. Tugas dan tanggung jawab guru

5. Optimalisasi kelompok kerja guru. ${ }^{14}$

Motivasi atau dorongan untuk melaksanakan pekerjaan yang muncul dari dalam diri sendiri lebih berati dibandingkan dengan dorongan muncul dari luas diri sendiri, sebab dorongan dari dalam diri sendiri untuk bekerja lebih dari dan merupakan kesadaran mental yang bersifat sementara dan merupakan persyaratan bagi timbulnya pelaksanaan pekerjaan dengan baik. Bila dorongan ada maka maka rintangan atau hambatan apapun dalam bekerja serta betapapun beratnya tugas yang dihadapi guru dilaksanakan dengan sebaik-baiknya.

Guru bertanggung jawab atas lancar dan maju mundurnya produktivitas pembelajaran, oleh karena itu perlu memiliki etos kerja yang baik, yaitu dengan datang dan bekerja secara baik, efektif, efisien, saling menghargai, bekerjasama dan demokratis.

Guru yang tidak memiliki etos kerja biasanya dalam bekerja asal-asalan, jika ada Kepala Sekolah baru giat bekerja tetapi jika tidak ada Kepala Sekolah bekerja semuanya.

Lingkungan yang baik untuk bekerja akan menumbuhkan perasaan kerasan dalam bekerja. Sebaliknya lingkungan kacau, kotor, tak teratur, hiruk pikuk, akan menimbulkan keengganan untuk bekerja dan tidak mungkin akan mencapai konsentrasi yang tinggi dalam bekerja, bahkan yang terjadi adalah kekacauan dan perasaan mudah letih.

Guru memiliki banyak tugas dan tanggung jawab baik terikat oleh dinas maupun di luar dinas. Tugas guru dikelompokkan menjadi 3 jenis, yaitu tugas dalam bidang profesi, tugas kemanusiaan, dan tugas dalam bidang kemasyarakat. Tugas dan tanggung jawab guru sebagai profesi meliputi mendidik, mengajar dan melatih, mendidik berarti meneruskan dan mengembangkan nilai - nilai hidup. Mengajar berarti meneruskan dan mengembangkan ilmu pengatahuan dan teknologi. Sedangkan melatih berarti mengembangkan keterampilan - keterampilan pada peserta diri. Tuda dan tanggung jawab dalam bidang kemanusiaan meliputi bahwa guru di sekolah hendaknya dapat menjadikan dirinya sebagai orang tua kedua artinya sebagai pengganti orang tua di rumah. Tugas dan tanggung jawab di bidang kemasyarakat meliuti keteladagan guru di lingkungan masyarakat karena dari guru di lingkungan masyarakat karena dari guru berkewajiban mencerdasakan kehidupan bangsa dan guru diharapkan dapat menyelesaikan aneka ragam permasalhan yang dihadapip masyarakat.

Mengenai kelompok kerja guru yang telah dibentuk sejak lama sebagai upaya meningkatkan kualtias guru dalam melaksanakan proses pembelajaran yang bermutu. Kelompok kerja guru berfungsi meningkatkan kemampuan guru sebagai tenaga kepenidikan yang berhubungan dengan materi pelajaran, persiapan mengajar, penggunaan media dan sumber belajar, penilaian, pelaksanaan bimbingan layanan serta diskusi guna mencari alternatif penyelesaian berbagai masalah dan penetapan keseragaman berbagai kegiatan.

\footnotetext{
${ }^{14}$ A. Tabrani Rusyan, dkk. Op. Cit. hlm. 17-39
} 


\section{Strategi Peningkatan Kinerja Guru}

Strategi peningkatan kinerja guru dalam rangka peningkatan mutu pendidikan menurut A. Tabrani Rusyan, dkk dapat dilakukan sebagai berikut :"1) Aktif dan kreatif, 2) Produktif, 3) Efektif dan Efisien."15

Guru yang memiliki budaya kinerja akan aktif dan kreatif dalam melaksanakan tugas pekerjaan yaitu memiliki kemampuan untuk menemukan komposisi, produksi atau gagasan - gagasan baru yang sebelumnya belum atau tidak ada dalam proses kinerja. Guru yang akitf dan kreatif dalam melaksanakan tugas dan pekerjaan sesuai dengan saran yang hendak di capai. Yakni memadukan semua upaya sehingga terjadi keserasian dalam keseluruhan kegiatan kinerja demi mempermudah tujuan. Proses kinerja merupakan suatu upaya mengorganisasikan suasana kegiatan kerja yang lebih baik. Upaya yang dilakukan meliputi :

1. Merencanakan program, prosedur sumber belajar.

2. Mempersiapkan alat Bantu untuk kelancaran proses kinerja

3. Memonitor kegiatan, mengevaluasi dan meramalkan kesulitan yang mungkin dihadapi dalam proses kinerja.

Adapun faktor-faktor yang mendukung terjadinya aktivitas dan kreativitas, guru adalah sebagai berikut :

1. Tersedianya waktu yang longgar

2. Kesempatan menyadari guru yang tidak memiliki tekanan dan mendapatkan kesempatan untuk menyadari.

3. Adanya dorongan baik yang datang dari dalam diri maupun yang datang dari luar dirinya.

4. Lingkungan yang merangsang baik di rumah, kantor, maupun di masyarakat. ${ }^{16}$

Guru teladan adalah guru yang produktif dalam melaksanakan tugas dan pekerjaan, karena produktivitas kinerja para guru akan meningkatkan hasil kinerja yang lebih baik.

Untuk menghasilkan sesuatu yang lebih baik dari pekerjaan, para guru hendaknya bekerja dengan produktivitas yang tinggi, sehingga tujuan kinerja yang telah ditetapkan dapat dicapai dengan baik pula:

1. Menyusun kerangka atau rencana sebelum melaksanakan tugas dan pekerjaan

2. Mampu bekerja secara efektif dan efisien

3. Mampu melihat hasil kinerja yang produktif dan tidak produktif.

Dari semua uraian diatas dapat disimpulkan bahwa guru yang efektif dan efisien akan menghasilkan proses pembelajaran yang bermutu karena guru tersebut

\footnotetext{
${ }^{15}$ Ibid. hlm. 150-163

${ }^{16}$ Ibid. hlm. 154
} 
memanfaatkan fasilitas pembelajaran dengan sebaik-baiknya serta penggunan yang berkualitas, sehingga tujuan pendidikan yang telah ditetapkan tercapai dengan baik. Efektivitas guru dapat dilihat pada :

1. Masukan merata

2. Keluaran yang banyak dan bermutu tinggi

3. Ilmu dan keluaran yang sesuai dengan kebutuhan masyarakat

4. Pendapatan tamatan dan keluaran yang memadai

\section{Kesimpulan}

Berdasarkan analisis dari teori - teori di atas dapat disimpulkan bahwa kinerja guru dalam penelitian ini adalah suatu keberhasilan yang dicapai guru dalam aktivitas mengajar atau proses belajar mengajar. Kinerja guru ini terlihat dari keterampilan membuat rencana pengajaran. Keterampilan mengajar dan kemampuan membina hubungan antar pribadi.

\section{Referensi}

Suryadi Prawiro Soentono, 1997. Manajemen Sumber Daya Manusia Kebijakan Kinerja Karyawan. Yogyakarta : BPFE. hlm. 2.

Alain Mitrani, dkk, 1990. Manajemen Sumber Daya Manusia Berdasarkan Kompetensi, Jakarta : Pustaka Utama Grafindo.

Tim Penyusun Kamus Pusat Pembinaan dan Pengembangan Bahasa,. 1996. Kamus Besar Bahasa Indonesia Edisi Kedua, Jakarta : Depdikbud Balai Pustaka.

IG. Wuryanto,1991. Manajemen Kepegawaian 2, Yogyakarta : Kanisius.

Hadi Supeno, 1989. Undang-Undang Indonesia, Nomor 11 Tahun 1989. Tentang Sistem Pendidikan Nasional Beserta Penjelasan. Jakarta : Balai Pustaka.

Wahjo Sumidjo. 2001. Kepemimpinan Kepala Sekolah. Jakarta : Raja Grafindo Persada. Muhibbin Syah, 1995. Psikologi Pendidikan. Dengan Pendekatan Baru, Bandung: Remaja Rosdakarya.

A. Tabrani Rusyan, dkk. 2001. Upaya Meningkatkan Kinerja Guru. Jakarta : Nusantara Lestari Ceria Pratama.

Harry Widyastono. 1990. Kinerja Guru Sekolah Dasar, Jakarta :Bina Aksara. Made Pidarta, 1990. Manajemen Pendidikan Indonesia. Jakarta : Bina Aksara. Moh Uzer Usman. 1995. Menjadi Guru Profesional . Bandung : Remaja Rosdakarya. 